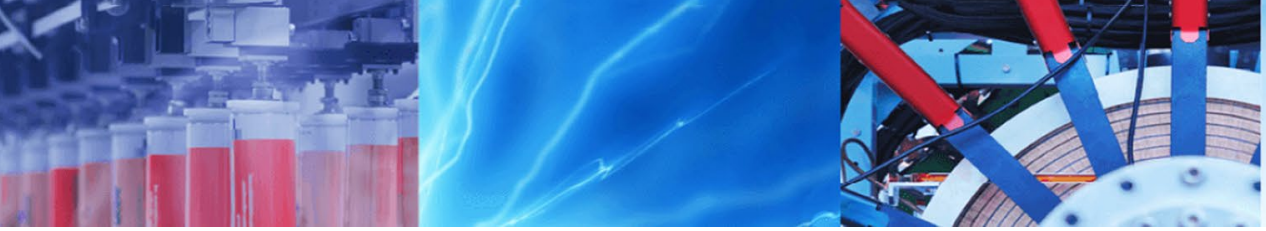

Research Article

\title{
Degradation of high energetic material hexahydro-1,3,5-trinitro-1,3,5-triazine (RDX) by a microbial consortium using response surface methodological approach
}

\author{
Kirty Sharma ${ }^{1,2} \cdot$ Praveen Sharma $^{2} \cdot$ S. Mary Celin ${ }^{1} \cdot$ Pramod Kumar Rai $^{1} \cdot$ Pritam Sangwan $^{1}$ (D)
}

Received: 12 September 2020 / Accepted: 21 December 2020 / Published online: 6 January 2021

(c) The Author(s) 2020 OPEN

\begin{abstract}
Soil and water get polluted with hexahydro-1,3,5-trinitro-1,3,5-triazine (RDX) during its manufacturing, storage and use for civil and military purposes. RDX has toxic effects on living and non-living environment and is a recalcitrant compound. Therefore, the remediation of this compound is necessary. Microbial degradation of RDX can be a suitable and sustainable option to reduce its deleterious impact on the environment. Therefore, the optimization for degradation of energetic munition compound RDX employing the consortium of native bacterial species, isolated from an actual contaminated site, was performed. The experiment was planned with three independent variables (initial RDX concentration, inoculum size of microbes, and duration of the experiment) and three dependent variables (percentage removal of RDX, optical density, and nitrite release). Both independent and dependent variables were analyzed by the response surface methodology (RSM) using the Box-Behnken design. The statistical analysis using analysis of variance (ANOVA) depicted a high regression coefficient, $R^{2}=0.9881$ with the statistically significant $p$-value fitted into a quadratic regression model for percentage removal of RDX. Results showed an initial RDX concentration of $40 \mathrm{mg} / \mathrm{L}$, inoculation size $6 \mathrm{~mL}$ and a time duration of 12 days was optimal for the reduction of RDX up to $80.4 \%$.
\end{abstract}

Keywords RDX · Microbial degradation · Contamination · Box-Behnken design · Microbial consortium

\section{Introduction}

Hexahydro-1,3,5-trinitro-1,3,5-triazine (RDX), an energetic material, is a major component that makes up the most of the explosive formulations these days [1, 2]. Its manufacturing, storage and utilization for civil and military purposes cause pollution of soil and water in the nearby areas, which is a serious threat to biotic and abiotic factors of the environment $[3,4]$. According to the US Department of Health and Human Services, Agency for Toxic Substances and Disease Registry (ATSDR 2012), RDX has been recognized as group $C$ potential carcinogen and can cause liver and kidney damage [5]. RDX does not occur in the environment naturally, and due to its recalcitrant property, it can exist in nature for a long duration of time causing contamination of abiotic components like air, water and soil. During World War II, energetic materials like RDX, octahydro-1,3,5,7-tetranitro-1,3,5,7-tetrazocine (HMX), 2, 4, 6 trinitrotoluene (TNT) have been extensively used, which has resulted in many contaminated sites all over the world making their contamination a global issue $[1,6,7]$. The general degradation time of RDX in nature can vary widely from $11.6 \%$ hydrolysis in seawater in 112 days to $t_{1 / 2}=2.5$ to 161.5 years in soil $[3,8]$. Methods like dumping at sea, incineration and disposal at specific landfill sites are generally employed for the management of RDX-contaminated

\footnotetext{
$\triangle$ Pritam Sangwan, pritam@cfees.drdo.in | ${ }^{1}$ Centre for Fire, Explosive and Environment Safety, Defence Research \& Development Organization, New Delhi 110054, India. ${ }^{2}$ Department of Environmental Science and Engineering, Guru Jambheshwar University of Science \& Technology, Hisar, Haryana 125001, India.
} 
wastes. This has a deleterious impact on the environment and results in further increase in air, water and soil pollution [9]. There is a need to find a sustainable remediation method to counter the problem of pollution caused by RDX contamination.

Microbial remediation is an eco-friendly and economical approach to remediate contaminated sites. Various studies for microbial remediation of soil and water contaminated with industrial waste containing dyes, phenols and petroleum products had been conducted by different researchers [10-12]. A number of studies had also been performed to evaluate explosive degradation potential of the microbes in anaerobic and aerobic conditions $[2,4,13$, 14]. Medha et al. and Nagar et al. $[15,16]$ studied microbial degradation of octahydro-1,3,5,7-tetranitro-1,3,5,7tetrazocine (HMX) and found a degradation of $87.7 \%$ in 15 days and $70 \%$ in 20 days, respectively. Khan et al. [14] found that aerobic degradation of energetic materials like RDX has many advantages over anaerobic degradation like faster degradation rate and lower toxicity of intermediates formed during degradation. Meta-analysis comparing previous literature by Sheehan et al. [17] shows that RDX biotransformation rate by bacteria in aerobic conditions is fastest as compared to anaerobic bacteria and fungi. Mass spectroscopy studies conducted by Nagar et al., Yadav et al., Kalsi et al. [18-20] during microbial degradation of RDX in aerobic conditions show the formation of nitrite, methylenedinitramine (MEDINA), formaldehyde, 1,3,5-trinitroso-1,3,5-triazinane (TNX), 1-nitro-3,5-dinitroso-1,3,5-triazinane (DNX). One of the most important by-products produced during RDX biodegradation is nitrite $\left(\mathrm{NO}_{2}{ }^{-}\right)$, which is analyzed in this study. It has been found that microbial interventions have the potential to remediate the sites contaminated due to industrial effluent [21]. Moreover, a microbial consortium can show a higher stability and more efficiency for microbial degradation than a pure culture of isolates.

Consortia of two microbes Paenibacillus aestuarii and Arthrobacter subterraneus were used for the study. Paenibacillus aestuarii is a rod-shaped, motile, spore-forming and gram-positive bacteria [22, 23], while Arthrobacter subterraneus is a cocci (diameter 0.8-1 $\mu \mathrm{m}$ ) and short rod shape occurring in clusters, in pairs, or singly, grampositive bacteria [24]. The RDX degradation potential of these bacterial species has not been explored so far. So in this study, a consortium of Paenibacillus aestuarii (isolate S4-TSB-1, MTCC No. 12854) and Arthrobacter subterraneus (isolate S5-TSB-17, MTCC No. 12883) was used to evaluate their RDX degradation potential in aqueous media in aerobic conditions. Response surface methodology (RSM) is an approach that uses statistical techniques and tools, which can be employed for improving and optimizing a process having numerous variables influencing the response. RSM employs lower-order polynomial equations and reduces the total number of experimental setups, which saves the resources and time. Box-Behnken model is a spherical, revolving RSM model that consists of at least 3 levels where independent variable is kept at one of three equally spaced values. In this model, the experimental combinations are equidistant at the edges of the process space and at the center. RSM involving Box-Behnken model for removal of contaminants using microbes has been employed by previous researchers also $[15,25]$. So the current study was planned using the Box-Behnken model of RSM with an objective to optimize experimental parameters for RDX degradation in aqueous phase employing an indigenous microbial consortium isolated from a contaminated site.

\section{Material and methods}

\subsection{Chemicals}

RDX was obtained from an explosive manufacturing facility in north India, with a purity of $>99 \%$. High-pressure liquid chromatography (HPLC)-grade acetonitrile was procured from Sigma-Aldrich, and triple distilled water was obtained from Millipore. All the other chemicals utilized for this study were purchased from standard manufacturers and were of analytical grade.

\subsection{Microorganism}

Soil and water samples were collected from contaminated sites near an explosive manufacturing facility in North India as per standard protocol using composite sampling, random systematic grid sampling and grab sampling methodology [26]. The bacterial strains from collected samples were isolated and identified by the Institute of Microbial Technology (IMTECH), Chandigarh, India. Bacterial species Paenibacillus aestuarii and Arthrobacter subterraneus were obtained in lyophilized form.

\subsection{Culture media and culture conditions}

The lyophilized microorganisms were revived, and the culture plates were maintained using trypticase soy agar (TSA) as a growth medium. TSA consisted of $15 \mathrm{~g}$ agar, $2.5 \mathrm{~g}$ dextrose, $2.5 \mathrm{~g}$ di-potassium phosphate, $5 \mathrm{~g} \mathrm{NaCl}, 3 \mathrm{~g}$ soya peptone and $17 \mathrm{~g}$ casein peptone, per liter of demineralized water. The isolates were subcultured in Erlenmeyer flasks using trypticase soy broth (TSB) as growth medium and incubated in an orbital shaker incubator at $120 \mathrm{rpm}$ and a temperature of $33 \pm 2{ }^{\circ} \mathrm{C}$ in sterile conditions. The cultures were later maintained in minimal salt medium 
(MSM), which had nutrients in a limited amount. Two types of MSM were prepared. MSM1 was used for making microbes adaptive to minimal salt medium, and MSM2 was used as a medium for growth in the batch experiment. MSM1 consisted of $1.74 \mathrm{~g} \mathrm{~K}_{2} \mathrm{HPO}_{4}, 1.36 \mathrm{~g} \mathrm{KH}_{2} \mathrm{PO}_{4}, 0.061 \mathrm{~g}$ $\mathrm{MgSO}_{4} \cdot 7 \mathrm{H}_{2} \mathrm{O}, 0.053 \mathrm{~g} \mathrm{NH}_{4} \mathrm{Cl}, 0.59 \mathrm{~g}$ succinic acid, $0.92 \mathrm{~g}$ glycerol, $0.900 \mathrm{~g}$ glucose, $0.278 \mathrm{mg} \mathrm{FeSO}{ }_{4} \cdot 7 \mathrm{H}_{2} \mathrm{O}, 11.09 \mathrm{mg}$ $\mathrm{CaCl}_{2} \cdot 2 \mathrm{H}_{2} \mathrm{O}, 0.015 \mathrm{mg} \mathrm{MnCl} \cdot 4 \mathrm{H}_{2} \mathrm{O}, 0.024 \mathrm{mg} \mathrm{H} \mathrm{BO}_{3}$, $0.0028 \mathrm{mg} \mathrm{ZnSO} \cdot \cdot 7 \mathrm{H}_{2} \mathrm{O}, 0.0024 \mathrm{mg} \mathrm{CuSO} \cdot 5 \mathrm{H}_{2} \mathrm{O}$ and $0.0071 \mathrm{mg} \mathrm{CoCl} \cdot 6 \mathrm{H}_{2} \mathrm{O}$ in one liter of demineralized water. MSM2 was prepared by omitting $\mathrm{NH}_{4} \mathrm{Cl}$, and RDX was substituted as the only nitrogen source for the microbes for further studies.

\subsection{Interaction studies}

Interaction studies were carried out to prepare consortium of microbes obtained from the site using the formula: ${ }^{n} C_{r}=n ! /(n-r) !(r) !$. where $C=$ combination of bacteria, $n=$ total no. of bacteria, $r=$ no. of bacterial strain in each combination. A total number of 4 different bacterial strains were used to prepare 6 different combinations for consortium using the above-mentioned formula. Each combination of consortium has 2 strains of bacteria. The consortium was prepared by inoculating $2 \mathrm{~mL}$ of freshly prepared pure culture broth of microbes in $100 \mathrm{~mL}$ sterile TSB media. The growth of bacterial species in consortium broth was confirmed by their colony-forming units (CFUs) on TSA. Microbes strain nos. S4-TSB-1 and S5-TSB-17 were found to have compatibility with each other and chosen for further study. Paenibacillus aestuarii colonies were of cream-white, whereas colonies of Arthrobacter subterraneus were yellowish in color and were uniformly present on the TSA plate after 3 days of incubation. The consortium culture of OD 1.21 in MSM1 media was used to perform the experiment.

\subsection{Batch experiment}

$1000 \mathrm{mg} / \mathrm{L}$ stock solution of RDX in acetonitrile was passed through a $0.22-\mu \mathrm{m}$ filter to make it sterile, and this stock was used to make the desired concentration of RDX, 20, 40 and $60 \mathrm{mg} / \mathrm{L}$. The inoculated MSM2 media was maintained on orbital shaker incubator at a temperature of $33 \pm 2{ }^{\circ} \mathrm{C}$ and $120 \mathrm{rpm}$. The consortium culture in MSM1 media was used to inoculate sterile MSM2 media, which contained different concentrations of RDX. The process of degradation can be significantly affected by different parameters like concentration of a contaminant, the volume of suspension (inoculation size) and time duration of the study [15, $25,27,28]$. All these parameters need to be optimized for efficient degradation studies. Experiments were planned using Design Expert 11 (Stat-Ease, Inc., Minneapolis, MN,
USA), which employs the RSM as a statistical tool [29]. Box-Behnken model was employed for the optimization of RDX degradation by a consortium of Paenibacillus aestuarii and Arthrobacter subterraneus. A total number of 17 runs were generated after applying values of independent variables which are 20,40 and $60 \mathrm{mg} / \mathrm{L}$ concentration of $\mathrm{RDX}, 2,4,6 \mathrm{ml}$ inoculation size and 4, 8, 12 days time duration. Different variable factors (independent variable), i.e., different concentrations of RDX with different inoculation size and sampling time interval used to set up the experiment, are given in Table 1.

\subsection{Analytical methods}

Optical density of samples was measured to study change in number of bacteria when they are subjected to different concentrations of RDX. Nitrite is an important metabolite produced during degradation of RDX. Three response parameters, i.e., optical density (OD), nitrite release and percentage removal of RDX, were analyzed. The bacterial growth was measured in the form of OD using the PerkinElmer UV-VIS spectrophotometer at $600 \mathrm{~nm}$. Nitrite release was analyzed by the diazotization method using the Hach DR1900 spectrophotometer. Concentration removal of RDX was analyzed using the HPLC Flexar from PerkinElmer Inc., USA. C18 column, having dimensions $3 \mu \mathrm{m}, 150 \times 4.6 \mathrm{~mm}$, was utilized as stationary phase and 50:50 v/v mixture of acetonitrile: Triple distilled water with $1 \mathrm{~mL} / \mathrm{min}$ flow rate was used as mobile phase. A photo diode array (PDA) detector was used for detection purposes. The HPLC samples were prepared as per the USEPA 8330A standard method (USEPA 2007).

\subsection{Statistical analysis}

Statistical analysis was carried out using Design Expert 11 (Stat-Ease, Inc., Minneapolis, MN, USA) for the analysis of variance (ANOVA) to estimate the significance of every term in fitted equations and to analyze goodness of fit [29]. In this study, factor variables were more than two; therefore, two-way ANOVA was implemented. A second-order polynomial model in which interaction terms were applied

Table 1 Independent variables and their coded levels used for optimization for RDX

\begin{tabular}{lrrr}
\hline Variables & \multicolumn{3}{c}{ Range and levels (coded) } \\
\cline { 2 - 4 } & \multicolumn{1}{c}{-1} & 0 & +1 \\
\hline Initial RDX concentration (mg/L) & 20 & 40 & 60 \\
Inoculation size (mL) & 2 & 4 & 6 \\
Time duration (days) & 4 & 8 & 12 \\
\hline
\end{tabular}


to exploratory results of the experiment can be written in the form of an understated equation

$Y=a_{o}+\Sigma a_{i} x_{i}+\Sigma a_{i i} x_{i}^{2}+\Sigma a_{i j} x_{i} x_{j}$

where $Y=$ percent removal of RDX, $a_{o}=$ offset term, $a_{i}=$ first-order main effect, $a_{i i}=$ Second-order main effect, $a_{i j}=$ interaction effect, $x_{i}$ and $x_{j}=$ input factors.

To obtain relation with the exploratory variables and their responses, 3D plots were produced and optimum variables were developed by the response surface methodology.

\section{Result and discussion}

\subsection{Reduction in concentration of RDX}

Various combinations of independent variables were generated using the response surface methodology with the Box-Behnken design. Table 2 shows all the independent variables and their responses, which were generated using this design. These combinations were tested for different parameters, which resulted in different responses in different combinations. Different response parameters obtained from experimental data for RDX degradation were fitted to the Box-Behnken design. The results of three different response variables, i.e., \% removal of RDX, optical density, and nitrite release, have been presented in the form of 3D response graphs.

Figure 1a shows the 3D response graph between initial concentrations of RDX, volume of suspension used, and percentage removal of the contaminant. It depicts that a maximum degradation of $80.4 \%$ RDX was achieved at an initial RDX concentration of $40 \mathrm{mg} / \mathrm{L}$, with inoculation size $6 \mathrm{~mL}$ and a time duration of 12 days, which was followed by degradation of $71.85 \%$ RDX at initial concentration of $40 \mathrm{mg} / \mathrm{L}$, with inoculation size $6 \mathrm{~mL}$ and a time duration of 4 days. A combination containing $60 \mathrm{mg} / \mathrm{L} \mathrm{RDX}$ with $4 \mathrm{~mL}$ inoculation size and a time period of 4 days was observed with minimum degradation of $52.7 \%$. The maximum degradation at optimum conditions was 0.52 times higher than the minimum degradation conditions. A smaller inoculation size and a higher concentration of RDX may have resulted in reduced survivability of the consortium and lower degradation at $60 \mathrm{mg} / \mathrm{L} \mathrm{RDX}$ with $4 \mathrm{~mL}$ inoculation size and a time period of 4 days.

Figure $1 \mathrm{~b}$ shows the 3D surface plot generated for optical density of consortium as a function of volume of suspension and initial RDX concentration. The maximum optical density of 1.93 was observed with the combination having $20 \mathrm{mg} / \mathrm{L}$ concentration of RDX and $6 \mathrm{~mL}$ volume of suspension in a time duration of 8 days, which was followed by optical density of 1.88 , with the combination having $20 \mathrm{mg} / \mathrm{L}$ concentration of RDX and $4 \mathrm{~mL}$ volume of suspension, in a time duration of 4 days. The minimum optical density of 0.08 was observed at $40 \mathrm{mg} / \mathrm{L}$

Table 2 Box-Behnken design matrix for three independent variables along with their observed response for RDX degradation

\begin{tabular}{|c|c|c|c|c|c|c|c|}
\hline Std & Run & $\begin{array}{l}\text { Factor } 1 \\
\text { A:Concentration } \\
(\mathrm{mg} / \mathrm{L})\end{array}$ & $\begin{array}{l}\text { Factor } 2 \\
\text { B:Volume of Sus- } \\
\text { pension (mL) }\end{array}$ & $\begin{array}{l}\text { Factor } 3 \\
\text { C:Time (days) }\end{array}$ & $\begin{array}{l}\text { Response } 1 \\
\text { Optical density }\end{array}$ & $\begin{array}{l}\text { Response } 2 \\
\text { Nitrite }\end{array}$ & $\begin{array}{l}\text { Response } 3 \\
\% \text { removal of RDX }\end{array}$ \\
\hline 17 & 1 & 40 & 4 & 8 & 1.25 & 0.44 & 62.97 \\
\hline 9 & 2 & 40 & 2 & 4 & 0.08 & 0.04 & 63.17 \\
\hline 4 & 3 & 60 & 6 & 8 & 0.67 & 0.3 & 63.88 \\
\hline 10 & 4 & 40 & 6 & 4 & 0.2 & 0.04 & 71.85 \\
\hline 15 & 5 & 40 & 4 & 8 & 1.25 & 0.44 & 62.97 \\
\hline 8 & 6 & 60 & 4 & 12 & 0.81 & 0.34 & 66.5 \\
\hline 13 & 7 & 40 & 4 & 8 & 1.25 & 0.44 & 62.97 \\
\hline 5 & 8 & 20 & 4 & 4 & 1.88 & 0.9 & 56.95 \\
\hline 14 & 9 & 40 & 4 & 8 & 1.25 & 0.44 & 62.97 \\
\hline 6 & 10 & 60 & 4 & 4 & 0.14 & 0.04 & 52.7 \\
\hline 2 & 11 & 60 & 2 & 8 & 0.21 & 0.24 & 53.4 \\
\hline 12 & 12 & 40 & 6 & 12 & 1.55 & 0.59 & 80.4 \\
\hline 7 & 13 & 20 & 4 & 12 & 1.87 & 0.98 & 68.0 \\
\hline 11 & 14 & 40 & 2 & 12 & 0.94 & 0.47 & 71.07 \\
\hline 3 & 15 & 20 & 6 & 8 & 1.93 & 0.54 & 65.6 \\
\hline 16 & 16 & 40 & 4 & 8 & 1.25 & 0.44 & 62.97 \\
\hline 1 & 17 & 20 & 2 & 8 & 1.61 & 1.06 & 57.25 \\
\hline
\end{tabular}



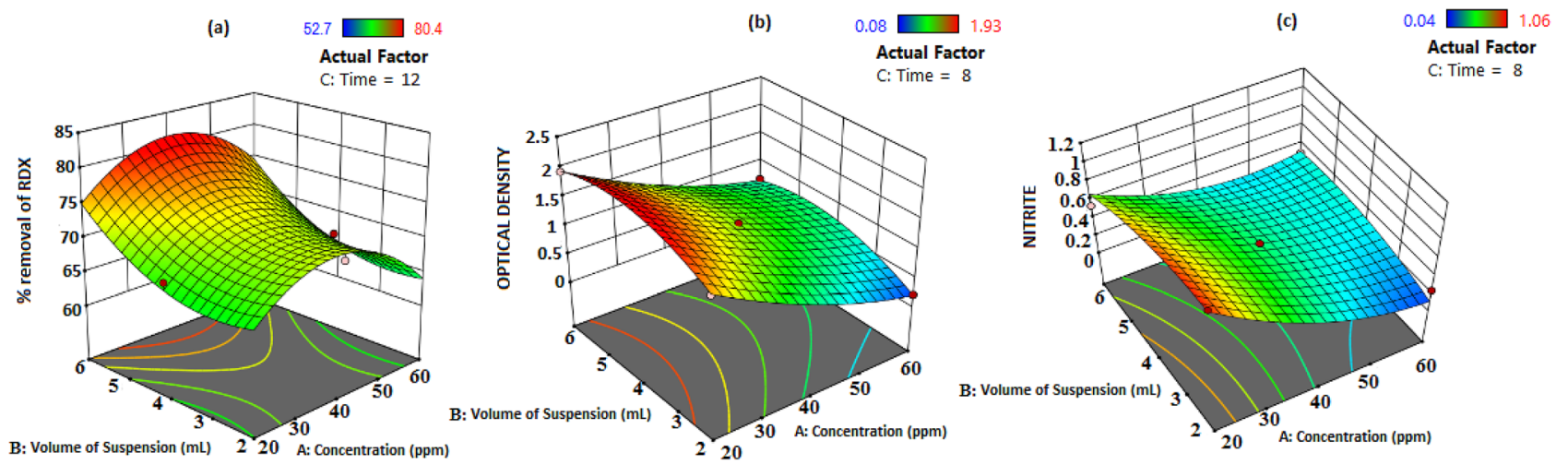

Design points above predicted value

$\mathrm{X} 1=\mathrm{A}:$ Concentration

Design points below predicted value

$\mathrm{X} 2 \mathrm{~B}$ : Volume of Suspension

Fig. $13 \mathrm{D}$ response surface plot for a \% removal of RDX, b optical density, $\mathbf{c}$ nitrite released by consortium as a function of volume of suspension and initial RDX concentration

concentration of RDX with $2 \mathrm{~mL}$ volume of suspension in a time duration of 4 days. The maximum optical density was 24.1 times higher than the minimum optical density. The better growth of microbes at combination having $20 \mathrm{mg} / \mathrm{L}$ concentration of RDX, $6 \mathrm{~mL}$ volume of suspension and time duration of 8 days may be due to the bigger inoculation size and lesser toxicity of RDX at a lower concentration [14]. The toxicity of RDX increased with increasing concentration, which may have lead to lesser growth at high concentration. Similar trends have been observed by Medha et al., while studying the degradation of HMX. The bacteria in consortium got acclimatized to RDX present in the MSM2 media in 4 days of inoculation and started utilizing it as a nitrogen source. It can be inferred that bacterial consortium can tolerate a high concentration of RDX, i.e., up to $60 \mathrm{mg} / \mathrm{L}$, but have a feeble growth after inoculation in initial days at this concentration.

Figure 1c shows the 3D surface plot for nitrite released by the consortium as a function of volume of suspension and initial concentration of RDX. The maximum nitrite release of $1.06 \mathrm{mg} / \mathrm{L}$ was observed with the combination having an initial RDX concentration of $20 \mathrm{mg} / \mathrm{L}$ and $2 \mathrm{~mL}$ volume of suspension in a time period of 8 days, which was followed by nitrite release of $0.98 \mathrm{mg} / \mathrm{L}$, with an initial RDX concentration of $20 \mathrm{mg} / \mathrm{L}$ and $4 \mathrm{~mL}$ volume of suspension in a time period of 12 days. $40 \mathrm{mg} / \mathrm{L}$ initial concentration of RDX with 2 and $6 \mathrm{~mL}$ volume of suspension in time duration of 4 days, and $60 \mathrm{mg} / \mathrm{L}$ initial concentration of RDX with $4 \mathrm{~mL}$ volume of suspension, in time duration of 4 days resulted in nitrite release of $0.04 \mathrm{mg} / \mathrm{L}$. The batch experiment did not show a fix trend of nitrite released during the experiment. This may be due to the instability of nitrite ion and its conversion to nitrate or its utilization by the growing microbes during the experiment. The presence of nitrite in the samples was due to the mineralization of RDX by the consortium in aerobic conditions. Similar results have been demonstrated by Thompson et al. and Andeer et al. [13, 30] while using aerobic bacteria Gordonia and Williamsia spp. to mineralize RDX. Earlier researchers also have shown RDX degradation up to $88 \%$ in 30 days, resulting in formation of nitrite, formaldehyde, formamide, methylenedinitramine (MEDINA), NDAB and nitrous oxide $[13,18,20,29]$.

\subsection{Analysis of variance}

The fitness and efficacy of the model were examined by two-way ANOVA and the regression coefficient. Table 3 shows ANOVA for the quadratic model, which indicates the assumed regression models for each response are significant and valid $(p<0.05)$. High significant ANOVA was obtained with $F$-values of $64.39,15.40$, and 9.48 for removal of RDX, optical density and nitrite released, respectively.

The $R^{2}$ value of the model was $0.9881,0.9519$, and 0.9241 for \% removal of RDX, optical density, and nitrite released, respectively. The predicted $R^{2}$ and adjusted $R^{2}$ were in reasonable agreement with each other in the case of $\%$ removal of RDX. This shows a good agreement with experimental outcomes and predictions by the model, which also depicts that the model was suitable to show the actual relation between the selected factors. The final predictive equation in terms of coded factors is listed below 


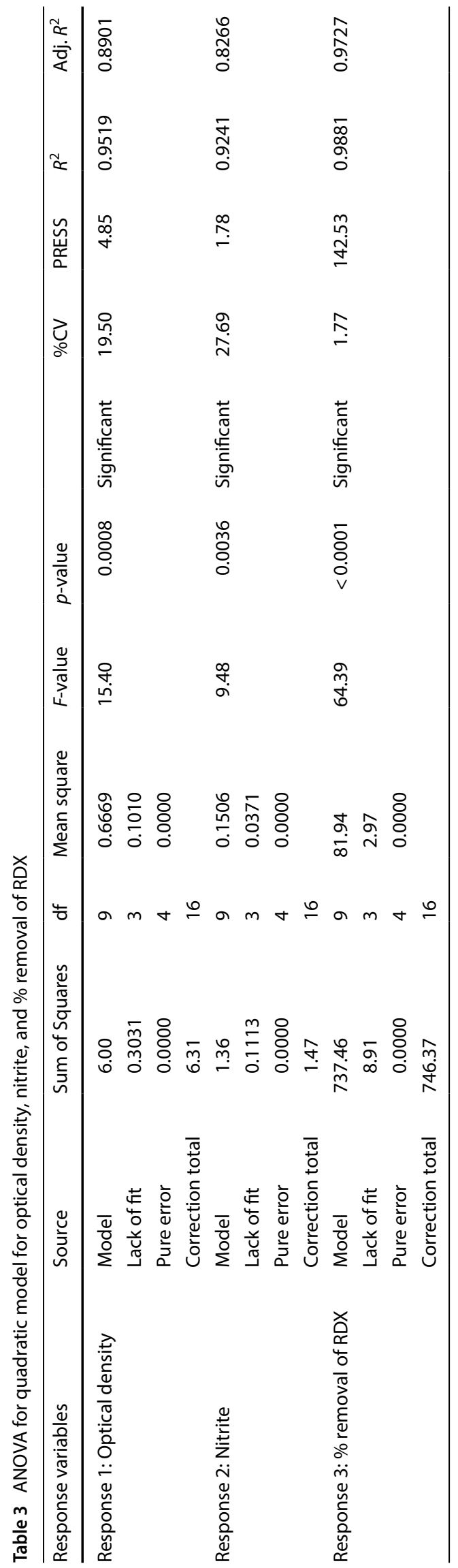

$$
\begin{aligned}
& \text { \%Removal of RDX }= 62.97-1.41 \times A+4.61 \times B \\
&+5.16 \times C+0.5325 \times A B \\
&+0.6875 \times A C+0.1625 \times B C \\
&-6.76 \times A^{2}+3.82 \times B^{2}+4.83 \times C^{2} \\
& \text { Optical density }= 1.25-0.6825 \times A+0.1888 \times C \\
&+ 0.0350 \times A B+0.1700 \times A C+0.225 \\
& \times B C+0.1688 \times A^{2}-0.3137 \times B^{2} \\
&-0.2438 \times C^{2} \\
& \text { Nitrite }=0.4400- 0.3200 \times A-0.0425 \times B \\
&+0.1700 \times C+0.1450 \times A B+0.0550 \\
& \times A C+ 0.0300 \times B C+0.1875 \times A^{2} \\
&-0.0925 \times B^{2}-0.0625 \times C^{2}
\end{aligned}
$$

where $A=$ concentration of $\operatorname{RDX}, B=$ volume of suspension, $C=$ time.

Figure 2a shows the graph of \% removal of RDX predicted versus actual, and Fig. $2 \mathrm{~b}$ shows the plot of optical density predicted versus actual. These graphs depict the actual values and predicted values separated by standard deviations. The actual values were the measured responses data of different runs, and the predicted values were evaluated from the model. The closeness of points in Fig. 2a shows a low value of standard deviation for $\%$ removal of RDX. In Fig. 2b, points on the plot are little scattered, which shows a higher value of standard deviation for optical density. Similar findings have been observed by Medha et al. [15], while studying the degradation of HMX using RSM approach.

\section{Conclusion}

The results show that the RDX removal capacity of consortium was influenced by all three factors, i.e., the initial concentration of the contaminant, the volume of suspension used, and the duration of the experiment. It can be inferred that up to $80.4 \%$ degradation of high energetic material RDX can be achieved by employing a consortium of Arthrobacter subterraneus and Paenibacillus aestuarii by using the Box-Behnken design for optimization of process variables. The ideal conditions for degradation of RDX were found out to be $40 \mathrm{mg} / \mathrm{L}$ initial RDX concentration, $6 \mathrm{~mL}$ inoculation size, and a time period of 12 days. The statistical examination and the closeness of exploratory outcomes showed the reliability of the regression model. Results showed that this native microbial consortium can biodegrade the concentration of RDX in the contaminated wastewater to a significant level reducing the expenses of 
(a)

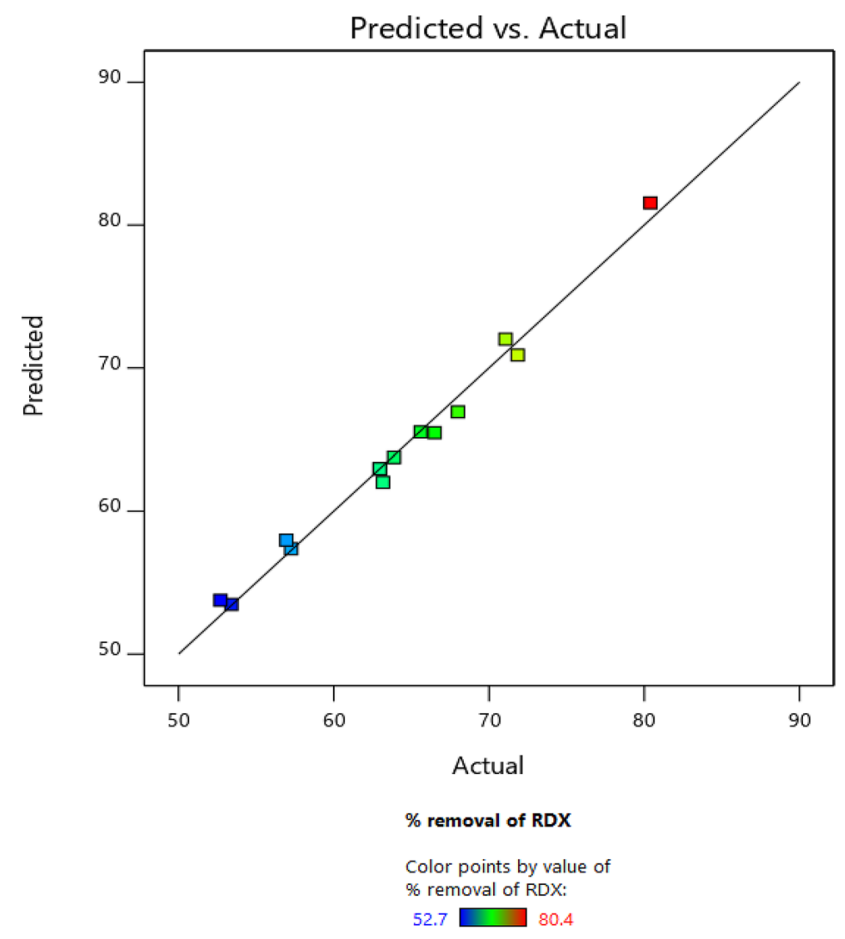

(b)

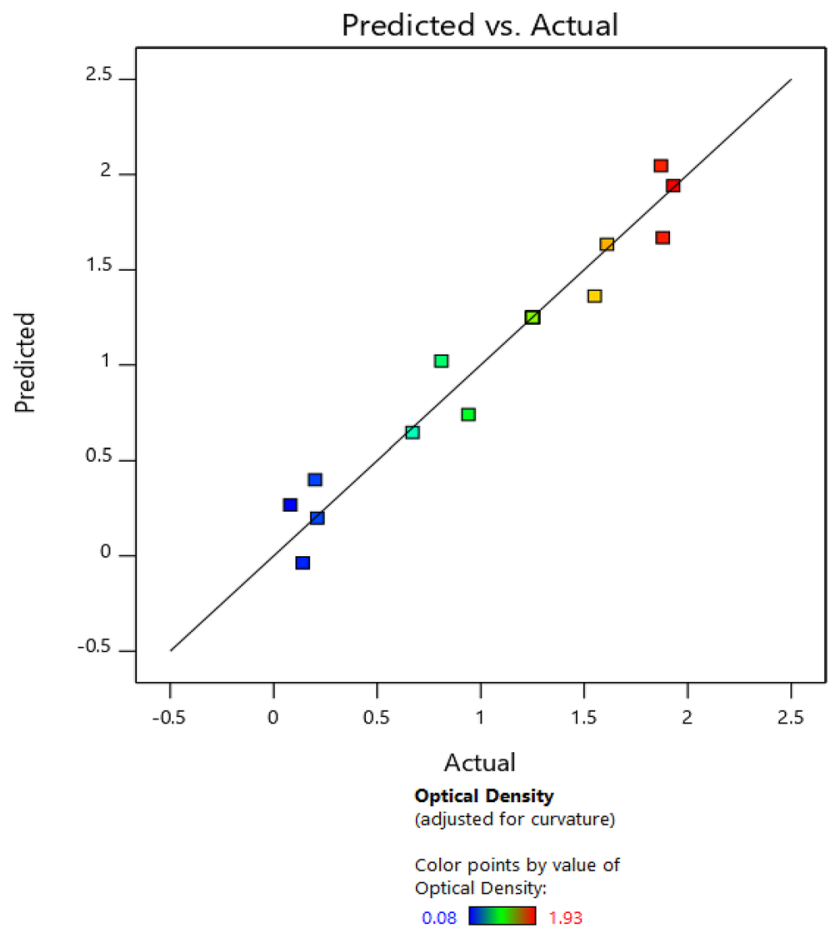

Fig.2 Predicted versus actual plot of responses $\mathbf{a} \%$ removal of RDX $\mathbf{b}$ optical density nitrite

its remediation and mitigating the problem of RDX-polluted water in an eco-friendly manner. The further intricate study is in progress to find out the mechanism and its secondary metabolites formed during the degradation of RDX and its applications in field conditions.

Acknowledgements Authors are thankful to Sh. Rajiv Narang, OS \& Director CFEES, Defence Research and Development Organization (DRDO), New Delhi, for encouraging research and providing necessary facilities and support. Authors are also thankful to Dr. S. Mayilraj, Principal scientist, IMTECH, CSIR, and Chandigarh for isolation and identification of microbes.

Funding Defence Research and Development Organisation (DRDO), Ministry of Defence, New Delhi, India.

Data availability Yes.

Code availability Not applicable.

\section{Compliance with ethical standards}

Conflicts of interest On behalf of all authors, the corresponding author states that there is no conflict of interest.

Consent to participate Not applicable.

Consent for publication Not applicable.
Ethical approval Not applicable.

Open Access This article is licensed under a Creative Commons Attribution 4.0 International License, which permits use, sharing, adaptation, distribution and reproduction in any medium or format, as long as you give appropriate credit to the original author(s) and the source, provide a link to the Creative Commons licence, and indicate if changes were made. The images or other third party material in this article are included in the article's Creative Commons licence, unless indicated otherwise in a credit line to the material. If material is not included in the article's Creative Commons licence and your intended use is not permitted by statutory regulation or exceeds the permitted use, you will need to obtain permission directly from the copyright holder. To view a copy of this licence, visit http://creativecommons .org/licenses/by/4.0/.

\section{References}

1. Ahmad F, Stephen SP, Newell CJ (2007) Remediation of RDX-and HMX-contaminated groundwater using organic mulch permeable reactive barriers. J Contam Hydrol 90(1-2):1-20. https:// doi.org/10.1016/j.jconhyd.2006.09.005

2. Liu Z, Lei Z, Liu Y, He Y (2015) Anaerobic biodegradation of RDX and HMX with different co-substrates. Chin J Chem Eng 23(4):704-709. https://doi.org/10.1016/j.cjche.2015.01.004

3. Abadin H, Smith C, Ingerman L, Llados FT, Barber LE Plewak D, and Diamond GL (2012) Toxicological profile for RDX,1215.https://www.atsdr.cdc.gov/ToxProfiles/tp78.pdf 
4. Cupples AM (2013) RDX degrading microbial communities and the prediction of microorganisms responsible for RDX bioremediation. Int Biodeter Biodegr 85:260-270. https://doi. org/10.1016/j.ibiod.2013.08.002

5. U.S. Department of health and human services public health service. Agency for toxic substances and disease registry (2012). Toxicological profile for RDX

6. Dimitrios K, Juhasz AL, Boopathy R, Comfort S (2011) Soils contaminated with explosives: environmental fate and evaluation of state-of-the-art remediation processes (IUPAC Technical Report). Pure Appl Chem 83(7):1407-1484. https://doi. org/10.1351/PAC-REP-10-01-05

7. Pichtel J (2012) Distribution and fate of military explosives and propellants in soil: a review. Hindawi publishing corporation, Applied and environmental soil science. https://doi. org/10.1155/2012/617236

8. Bernstein A, Adar E, Ronen Z, Lowag H, Stichler W, Meckenstock RU (2010) Quantifying RDX biodegradation in groundwater using $\delta 15 \mathrm{~N}$ isotope analysis. J Contam Hydrol. https:// doi.org/10.1016/j.jconhyd.2009.10.010

9. Clark B, Boopathy R (2007) Evaluation of bioremediation methods for the treatment of soil contaminated with explosives in Louisiana army ammunition plant, Minden. Louisiana J Hazard Mater 143:643-648

10. Omer FS, Nalan OSK, Asli C, Turgay T, Tamer U (2017) Bacteria encapsulated electrospun nanofibrous webs for remediation of methylene blue dye in water. Colloid Surf B. https://doi. org/10.1016/j.colsurfb.2017.01.034

11. Sepehr S, Shahnavaz B, Asoodeh A, Karrabi M (2019) Biodegradation of phenol by cold-tolerant bacteria isolated from alpine soils of Binaloud Mountains in Iran. J Environ Sci Health A Tox Hazard Subst Environ Eng 54(4):367-379. https://doi. org/10.1080/10934529.2018.1553818

12. Shahi A, Aydin S, Ince B, Ince $O$ (2016) Reconstruction of bacterial community structure and variation for enhanced petroleum hydrocarbons degradation through biostimulation of oil contaminated soil. Chem Eng J 306:60-66

13. Peter A, StahI DA, Lillis L, Strand SE (2013) Identification of microbial populations assimilating nitrogen from RDX in munitions contaminated military training range soils by high sensitivity stable isotope Probing. Environ Sci Technol 47(18):10356-10363

14. Khan MI, Yang J et al (2015) Improved RDX detoxification with starch addition using a novel nitrogen-fixing aerobic microbial consortium from soil contaminated with explosives. J Hazard Mater 287:243-251. https://doi.org/10.1016/j.jhazm at.2015.01.058

15. Medha A, Sangwan P, Bala K (2020) Optimization of process parameters for degradation of $\mathrm{HMX}$ with Bacillus toyonensis using response surface methodology. Int J Environ Sci Te. https ://doi.org/10.1007/s13762-020-02783-0

16. Nagar S, Shaw AK, Anand S, Celin SM, Rai PK (2018) Aerobic biodegradation of HMX by Planomicrobium flavidum. 3Biotech 8(11):455

17. Sheehan PL, Sadovnik R, Kukor JJ, Bennett JW (2020) Meta analysis of RDX biotransformation rate by bacteria and fungi. Int Biodeterior Biodegrad 146:104814
18. Nagar S, Shaw AK, Celin SM AS, Rai PK (2020) Biodegradation of octogen and hexogen by Pelomonas aquatica strain WS2R2A-65 under aerobic condition. Environ Technol. https://doi. org/10.1080/09593330.2020.1812731

19. Yadav S, Sharma A, Khan MA, Sharma R, Celin M, Malik A, Sharma $S$ (2020) Enhancing hexahydro-1, 3, 5-trinitro-1, 3, 5-triazine (RDX) remediation through water-dispersible Microbacterium esteraromaticum granules. J Environ Manag. https://doi. org/10.1016/j.jenvman.2020.110446

20. Kalsi A, SharmaJG CSM (2020) Aerobic biodegradation of high explosive hexahydro-1,3,5- trinitro-1,3,5-triazine by Janibacter cremeus isolated from contaminated soil. Biotechnol Lett. https ://doi.org/10.1007/s10529-020-02946-6

21. Ahmad M, Pataczek L, Hilger TH (2018) Perspectives of microbial inoculation for sustainable development and environmental management. Front Microbiol. https://doi.org/10.3389/fmicb .2018 .02992

22. Zhao JS, Manno D, Hawari J (2007) Abundance and diversity of Octahydro-1,3,5,7-tetranitro-1,3,5,7-tetrazocine (HMX)metabolizing bacteria in UXO-Contaminated marine sediments. FEMS Microbiol Ecol 59(3):707-717. https://doi.org/10 $.1111 / j .1574-6941.2006 .00248 . x$

23. Bae YJ, Kim KY, Kim JH, Lee K, Cho JC, Cha CJ (2010) Paenibacillus aestuarii sp. Nov., isolated from an estuarine wetland. Int J Syst Evol. https://doi.org/10.1099/ijs.0.011544-0

24. Chang HW, Bae JW, Nam YD (2007) Arthrobacter subterraneus sp. nov., isolated from deep subsurface water of the south coast of Korea. J Microbiol Biotechnol 17(11):1875-79

25. Sangwan P, Celin SM, Hooda L (2015) Response surface methodological approach for optimizing process variables for biodegradation of 2, 4, 6-trinitrotoluene using Acinetobacter noscomialis. Eur J Adv Eng Technol 2(4):51-56

26. Environmental Protection Agency (EPA). Validated method 8330B: nitroaromatics, nitramines, and nitrate esters by high performance liquid chromatography (HPLC) (revised 2006)

27. Sharma P, Singh L, Dilbaghi N (2009) Response surface methodological approach for the decolorization of simulated dye effluent using Aspergillus fumigatus fresenius. J Hazard Mater 161(23):1081-1086. https://doi.org/10.1016/j.jhazmat.2008.04.085

28. Sharma P, Singh L (2012) Application of response surface analysis for biodegradation of azo reactive textile dye using Aspergillus foetidus. J Basic Microbiol 52(3):314-323. https://doi. org/10.1002/jobm.201100060

29. Design Expert 11 (Stat- Ease, Inc., Minneapolis, MN, USA) https ://www.statease.com/docs/v11/

30. Thompson KT, Crocker FH, Fredrickson HL (2005) Mineralization of the cyclic nitramine explosive hexahydro-1,3,5-trinitro-1,3,5-triazine by Gordonia and Williamsis spp. Appl Environ Microbiol 71(12):8265-8272. https://doi.org/10.1128/ AEM.71.12.8265-8272.2005

Publisher's Note Springer Nature remains neutral with regard to jurisdictional claims in published maps and institutional affiliations. 